\title{
An approach to the Choice of a Supply Management Model in Conglomerates Operating at the Markets of Machine-building industry
}

\author{
Gennady D. Antonov ${ }^{1,2, a}$, Olga P. Ivanova ${ }^{1,2,3}$ \\ ${ }^{1}$ National Research Tomsk Polytechnic University, 634050, Lenin Avenue, 30, Tomsk, Russia \\ ${ }^{2}$ Kemerovo Institute of Qualification Improvement and Retraining, 650060, Michurina str., 13a, Kemerovo, Russia \\ ${ }^{3}$ Kemerovo State University, 650060, Krasnaya str., 6, Kemerovo, Russia
}

\begin{abstract}
Strategic and managerial analysis shows that currently many conglomerates including those in the machine-building industry do not have established approaches to formation of a purchasing management system for their primary activity; some problems of purchasing model choice methodology lack theoretical development. In the given work the authors specify the list, the characteristics and the combination of estimated macrofactors influencing the choice of the principal supply model for the purposes of forming an optimal purchasing system of conglomerates. Supply management functions are distributed within the supply system of the holding company
\end{abstract}

\section{Introduction}

Conglomerates are capable of better exploitation of sources of values dealing with various business areas in a more efficient way than it is done by specialized companies. At the same time the conglomerates face the problem of company structuring and running for the purposes of the best exploitation of these sources of values. In spite of the theoretical argumentation for the conglomerates consisting of multiple subdivisions and empirical evidence of their efficiency, research shows that combining advantages of decentralization and coordination is still a problem for conglomerates [1]. Henry Mintzberg [2] highlights two structural peculiarities of conglomerates including a number of subdivisions which limit decentralization and their ability to adapt. First, limitation of decentralization reveals itself in limiting the freedom-to-operate of subdivision managers by the headquarters in case of variations in the subdivision activities. Second, the problems of coexistence of different inside cultures and management systems of various subdivisions, an opportunity of differentiation according to their business requirements face management standardization at the subdivision level implemented by means of common monitor systems, processes of development control, corporate culture. Besides, analysis of conglomerates functioning practice, including those at the markets of machine-building industry, provides evidence that we need solution of problems of choosing a corporate model of corporate purchasing management, which are, first of

\footnotetext{
a Corresponding author: gda-kuzbass@rambler.ru
}

all, associated with centralization optimization and decentralization of purchasing functions.

\section{Analysis of the methods of corporate purchasing systems organization}

In the works [3-8] the scientists describe the following approaches developed as a result of research aimed at studying the state and methods of building corporate purchasing systems in some corporations of the USA and Western Europe:

1. An approach based on the combination of two macrofactors: homogeneity of companies (similarity of such characteristics as purchased assortment, capital funds used, climatic conditions, common suppliers, etc.) and development of a purchasing structure at every company;

2. An approach supposing purchasing a model choice depending upon the combination of such factors as development of a purchasing function and corporate coherency revealing itself in closeness of company management systems for the companies included into the corporation, similarities in their business culture, existence of corporate ideology and politics;

3. An approach reflecting dependence of financial results of the corporation on supply chain management under the conditions of certain fullness of supply functions and a degree of finished product uniqueness.

Depending on the paired combination of macrofactor data assessment the practicability of centralization, 
decentralization or a hybrid purchasing model (cooperation, shared purchasing controlled by the leading buying agent of one of the companies) is determined. The advantages of the given approaches include not only easiness and application of only two generalized parameters in each of them but also the application of a simple scale of factor assessment: highlow.

When estimating the opportunities of applying the given approaches to determining the purchasing model in a conglomerate we should analyze the result of the use of mentioned factors choice rules. Thus, for example, application of the first approach, based on the combination of homogeneity of the companies and development of a purchasing structure in every company to determine the model of purchasing management in a conglomerate, brought us to the following conclusions. First, in respect to a conglomerate there arises the necessity of correcting the factor "homogeneity of the company". It is reasonable to apply only the similarity of such characteristics as purchased assortment, climatic conditions and common suppliers for a conglomerate, including the one in machine-building industry. Second, according to the rule of supply, the model choice for the given approach, high homogeneity of the companies and a well-developed supply function determines the necessity of decentralization as decentralized supply services are capable of ensuring the purchasing process on their own and, thus, are more likely to ignore the supply subdivision in the corporate centre. Therefore, the given approach does not take into consideration the opportunity of obtaining advantages from supply centralization due to consolidation of purchase amount, i.e. reducing purchasing prices and costs associated with decentralized supply services operating.

According to the rules of choice in the second approach (a combination of factors "corporate coherence" and "development of supply function"), in case of having the corporate strategy, similarity of organizational structures of the companies, i.e. having high corporate coherence and development of supply function (for example when each subdivision has its own supply subdivision), the process of purchasing should be centralized. Thus the given approach does not take into account the peculiarities of supplying the subdivisions of a conglomerate, such as wide purchased assortment which is especially characteristic of supply market of machinebuilding subdivisions.

According to the rules of supply, the model choice in the third approach (combination of factors - fullness of supply functions and the degree of finished product uniqueness) means that supply centralization is advantageous for manufacturing relatively widespread or raw products, whereas decentralization - for manufacturing of a unique product. Within a conglomerate, product characteristics in terms of uniqueness/abundance differ for every subdivision. The given aspect, first of all, is characteristic for corporations which include machine-building subdivisions. Besides, specialized supply services of subdivisions, as a rule, complete the whole and not narrow range of supply functions. Due to this fact application of the given approach as it is to a conglomerate leads to a wrong choice of the supply model.

\section{Results}

Basing on the considered approaches, taking their advantages and disadvantages into consideration, let us formulate the rules of selecting the principle model of supply organization in a conglomerate by means of specifying the list, combinations and characteristics of the estimated macrofactors. The specified list and characteristics of macrofactors are presented in Table 1.

As in a conglomerate homogeneity of subdivisions, a priori low application of the given factor is senseless. We should estimate the possibility of synergy from the combination of different branches subdivision potentials for manufacturing new, unique, competitive products including machine-building one. We consider it possible to estimate both fullness and development of the supply function as an integrated macrofactor. Development of the supply function to a certain extent is impossible without fullness of applied subfunctions of supply. Thus, from five macrofactors considered for selecting a corporate supply model we highlight three: corporate coherence, development and fullness of supply function, uniqueness of a manufactured product.

Table 1. The list and the characteristics of the factors of selecting a supply model for a conglomerate operating at the machine-building industry market

\begin{tabular}{|c|c|c|}
\hline Macrofactor & Factor & Factor characteristic \\
\hline \multirow[t]{6}{*}{$\begin{array}{l}\text { Corporate } \\
\text { coherence }\end{array}$} & $\begin{array}{l}\text { Independence of } \\
\text { subdivisions }\end{array}$ & $\begin{array}{l}\text { Limited independence } \\
\text { of subdivisions }\end{array}$ \\
\hline & $\begin{array}{l}\text { Having a } \\
\text { corporate } \\
\text { strategy }\end{array}$ & $\begin{array}{l}\text { Complexity of strategic } \\
\text { planning for a } \\
\text { conglomerate }\end{array}$ \\
\hline & $\begin{array}{l}\text { Single } \\
\text { accounting } \\
\text { policy }\end{array}$ & $\begin{array}{l}\text { Complexity of } \\
\text { implementing single } \\
\text { accounting policy }\end{array}$ \\
\hline & $\begin{array}{c}\text { Single } \\
\text { personnel } \\
\text { policy. } \\
\text { Single system } \\
\text { of education. }\end{array}$ & $\begin{array}{l}\text { A possibility of } \\
\text { conducting single } \\
\text { personnel policy and } \\
\text { implementing the } \\
\text { general diversified } \\
\text { system of education }\end{array}$ \\
\hline & $\begin{array}{l}\text { Planning of } \\
\text { activities }\end{array}$ & $\begin{array}{l}\text { Planning of financial } \\
\text { results and growth areas } \\
\text { at the conglomerate } \\
\text { level. }\end{array}$ \\
\hline & $\begin{array}{l}\text { Common use of } \\
\text { the same } \\
\text { transport } \\
\text { corridors }\end{array}$ & $\begin{array}{l}\text { Using single transport } \\
\text { corridors (internal and } \\
\text { external) in the situation } \\
\text { of spatial unity, spatial } \\
\text { juxtaposition }\end{array}$ \\
\hline \multirow{2}{*}{$\begin{array}{l}\text { Developme } \\
\text { nt and } \\
\text { fullness of } \\
\text { supply } \\
\text { functions* }\end{array}$} & $\begin{array}{l}\text { The quality of } \\
\text { supply function } \\
\text { execution }\end{array}$ & \multirow{2}{*}{$\begin{array}{l}\text { As a rule, with respect } \\
\text { to different subdivisions } \\
\text { it is highly estimated as } \\
\text { supply decentralization } \\
\text { determines the necessity } \\
\text { of development of all }\end{array}$} \\
\hline & $\begin{array}{c}\text { Providing } \\
\text { workers of } \\
\text { supply services }\end{array}$ & \\
\hline
\end{tabular}




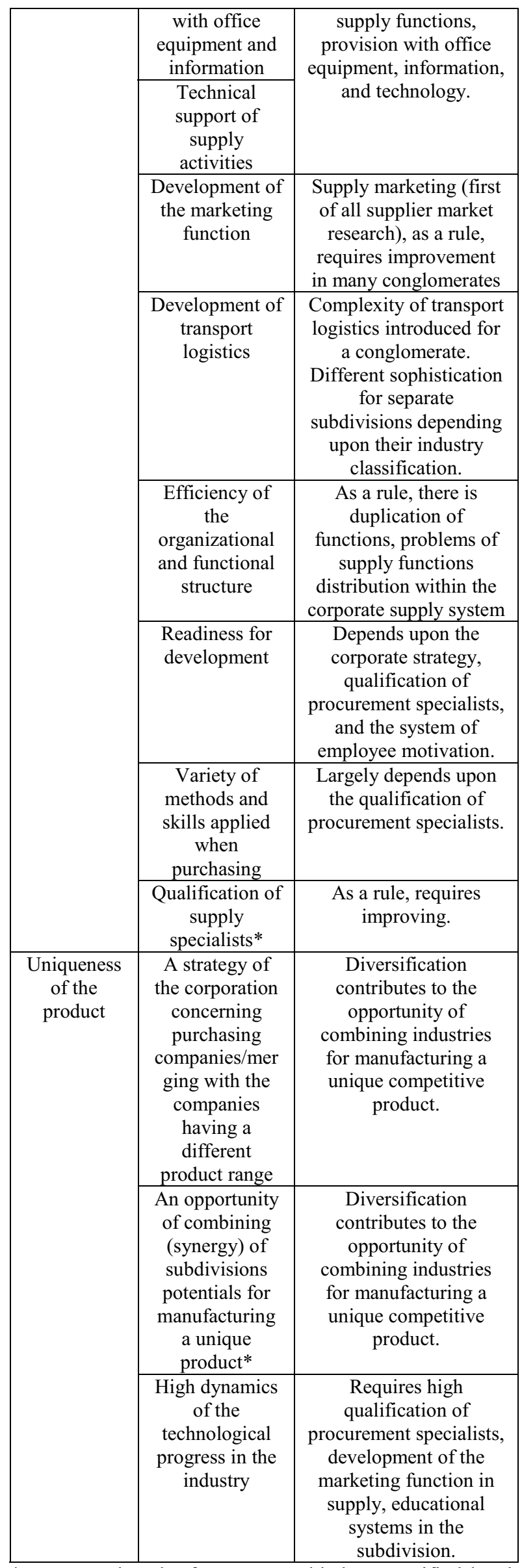

* - means that the factor was added or specified by the authors.
The choice of a supply model (centralized, decentralized, hybrid (mixed)) of a conglomerate supposes analyzing the possible variants of the given macrofactors combination obtaining low or high assessment (Table 2). The hybrid (mixed) model is the corporate supply preferred model in most variants of the factor combination. Thus, to ensure the application of approaches to the choice of a principle model of supply management in a conglomerate we specified the list, the characteristics and the combination of the estimated macrofactors.

Table 2. The choice of the principle model of supply on the base of the macrofactor estimation and combination

\begin{tabular}{|c|c|c|c|}
\hline \multicolumn{3}{|c|}{ Factor estimation (low level, high level) } & \multirow{2}{*}{$\begin{array}{l}\text { A preferred } \\
\text { model of } \\
\text { supply }\end{array}$} \\
\hline $\begin{array}{l}\text { Corporate } \\
\text { coherence }\end{array}$ & $\begin{array}{l}\text { Development } \\
\text { and fullness of } \\
\text { a supply } \\
\text { function }\end{array}$ & $\begin{array}{l}\text { Uniqueness } \\
\text { of the } \\
\text { product }\end{array}$ & \\
\hline low level & low level & low level & $\begin{array}{l}\text { Decentraliz } \\
\text { ation }\end{array}$ \\
\hline low level & low level & high level & $\begin{array}{c}\text { A hybrid } \\
\text { model (a } \\
\text { combinatio } \\
n \text { of } \\
\text { decentraliz } \\
\text { ation with } \\
\text { formation } \\
\text { of groups } \\
\text { uniting } \\
\text { several } \\
\text { buying } \\
\text { agents) }\end{array}$ \\
\hline high level & low level & low level & $\begin{array}{c}\text { Centralizati } \\
\text { on }\end{array}$ \\
\hline low level & high level & low level & $\begin{array}{l}\text { Decentraliz } \\
\text { ation }\end{array}$ \\
\hline high level & high level & high level & $\begin{array}{c}\text { A hybrid } \\
\text { model with } \\
\text { the } \\
\text { developed } \\
\text { corporate } \\
\text { manageme } \\
\text { nt centre }\end{array}$ \\
\hline high level & high level & low level & $\begin{array}{c}\text { A variant } \\
\text { of a hybrid } \\
\text { centre- } \\
\text { coordinate } \\
\text { d model }\end{array}$ \\
\hline low level & high level & high level & $\begin{array}{c}\text { A hybrid } \\
\text { model (a } \\
\text { combinatio } \\
n \text { of } \\
\text { decentraliz } \\
\text { ation with } \\
\text { formation } \\
\text { of groups } \\
\text { uniting } \\
\text { several } \\
\text { buying } \\
\text { agents) }\end{array}$ \\
\hline high level & low level & high level & $\begin{array}{c}\text { Centralizati } \\
\text { on }\end{array}$ \\
\hline
\end{tabular}

Combination of the given macrofactors allows determining the principle supply model (centralization, decentralization, hybrid (mixed)). 
Forming of mixed (hybrid) model of supply in conglomerate, diversified holding company, providing functioning efficiency demands distribution of supply management functions between a head organization, branch holding companies, and branch trade houses. The solution of this task should be based on the combination of function centralization and decentralization, providing the possibility for development and maintenance of internal competition between trade houses and supply departments; and optimization of holding company supply system arrangement. Holding supply system is viewed as an interrelated complex of branch trade houses, supply departments and a corporate center supply department in the diversified holding management company. Development and maintenance of internal competition between branch trade houses and supply departments demand development of tactical operating functions on this level, as well as a part of administrative functions. Supply management functions distribution and management subjects can be seen in table 3 .

Table 3. Supply management functions distribution in a conglomerate holding company

\begin{tabular}{|c|c|c|}
\hline Function & $\begin{array}{l}\text { Function subject } \\
\text { matter }\end{array}$ & $\begin{array}{l}\text { A supply system } \\
\text { subject, performing a } \\
\text { function }\end{array}$ \\
\hline \multirow[t]{5}{*}{ Planning } & $\begin{array}{c}\text { External and internal } \\
\text { environment research, } \\
\text { commodity items } \\
\text { market research }\end{array}$ & Supply department \\
\hline & $\begin{array}{l}\text { Material resources } \\
\text { forecasting and } \\
\text { requirement } \\
\text { determination }\end{array}$ & $\begin{array}{l}\text { Branch trade houses } \\
\text { Supply department }\end{array}$ \\
\hline & $\begin{array}{l}\text { Production supplies } \\
\text { optimization }\end{array}$ & $\begin{array}{l}\text { Branch trade houses } \\
\text { Supply department }\end{array}$ \\
\hline & $\begin{array}{c}\text { Materials requirement } \\
\text { planning }\end{array}$ & Branch trade houses \\
\hline & $\begin{array}{l}\text { Operational supply } \\
\text { planning }\end{array}$ & Branch trade houses \\
\hline \multirow[t]{7}{*}{$\begin{array}{l}\text { Administr } \\
\text { ative }\end{array}$} & $\begin{array}{c}\text { Gathering information } \\
\text { on a necessary } \\
\text { product }\end{array}$ & $\begin{array}{l}\text { Branch trade houses } \\
\text { Supply department }\end{array}$ \\
\hline & $\begin{array}{l}\text { Taking part in trade } \\
\text { fairs, selling } \\
\text { exhibitions, auctions } \\
\text { etc. }\end{array}$ & Supply department \\
\hline & $\begin{array}{l}\text { Analysis of resource } \\
\text { demand satisfaction } \\
\text { sources for the } \\
\text { purpose of selecting } \\
\text { an optimal source } \\
\end{array}$ & $\begin{array}{l}\text { Branch trade houses } \\
\text { Supply department }\end{array}$ \\
\hline & $\begin{array}{c}\text { Conclusion of } \\
\text { business contracts on } \\
\text { delivery with } \\
\text { suppliers }\end{array}$ & Branch trade houses \\
\hline & $\begin{array}{c}\text { Organizing of supply } \\
\text { delivery }\end{array}$ & Branch trade houses \\
\hline & $\begin{array}{c}\text { Organizing of storage } \\
\text { facilities }\end{array}$ & $\begin{array}{l}\text { Branch trade houses } \\
\text { Supply department }\end{array}$ \\
\hline & $\begin{array}{l}\text { Providing of holdings, } \\
\text { factories, workshops, } \\
\text { work sections, work } \\
\text { places with necessary }\end{array}$ & Branch trade houses \\
\hline
\end{tabular}

\begin{tabular}{|c|c|c|}
\hline & material resources & \\
\hline $\begin{array}{l}\text { Regulatio } \\
\text { n of } \\
\text { material } \\
\text { resources }\end{array}$ & $\begin{array}{l}\text { Adjusting of delivery } \\
\text { dates, forms of } \\
\text { payment to the } \\
\text { suppliers etc. }\end{array}$ & Branch trade houses \\
\hline \multirow[t]{6}{*}{$\begin{array}{l}\text { Enforcing } \\
\text { and } \\
\text { coordinati } \\
\text { ng }\end{array}$} & $\begin{array}{l}\text { Controlling of } \\
\text { suppliers contractual } \\
\text { commitments, } \\
\text { monitoring of } \\
\text { delivery dates }\end{array}$ & Branch trade houses \\
\hline & $\begin{array}{c}\text { Controlling of } \\
\text { material resources use } \\
\text { at the place of } \\
\text { production }\end{array}$ & $\begin{array}{l}\text { Branch trade houses } \\
\text { Supply department }\end{array}$ \\
\hline & $\begin{array}{l}\text { An incoming quality } \\
\text { and content of } \\
\text { delivery control }\end{array}$ & Branch trade houses \\
\hline & $\begin{array}{l}\text { Controlling of } \\
\text { production supply }\end{array}$ & Branch trade houses \\
\hline & $\begin{array}{l}\text { Recovery of claims to } \\
\text { the suppliers and } \\
\text { transportation } \\
\text { organizations }\end{array}$ & Branch trade houses \\
\hline & $\begin{array}{c}\text { Holding supply } \\
\text { system efficiency } \\
\text { analysis, elaboration } \\
\text { of measures, aimed at } \\
\text { supply coordination } \\
\text { and its efficiency }\end{array}$ & Supply department \\
\hline
\end{tabular}

\section{Conclusion}

Thus, modernization of the considered methods of corporate supply systems development in respect to conglomerates, particularly the ones operating at the machine-building market results in authors suggesting an approach to the choice of an optimal supply model in a conglomerate. To be more precise the authors formed the matrix of the macrofactor combination influencing the choice of the principle supply model (centralization, decentralization, hybrid (mixed)). The list, the characteristics and the combination of the estimated macrofactors were specified. We suggested a model of distribution of supply management functions between supply system subjects within a holding company, based on the combination of function centralization and decentralization, providing the possibility for development and maintenance of internal competition between trade houses and supply departments, and optimization of holding company supply system arrangement.

\section{References}

1. R. Grant, Contemporary Strategy Analysis (Piter, Saint-Petersburg, 2008)

2. H. Mintzberg, Designing Effective Organizations (Prentice-Hall, Englewood Cliffs, NJ, 1983)

3. J. David, Y. Hwang, J. Reneau, Arizona State University (1999)

4. H. Fearon, M. Leanders, Centre for Advanced Purchasing Studies (Tempe, Arizona, 1996) 
5. F. Rozenmeijer, Technische Universiteit Eindhoven (2000)

6. Information

on

http://www.purchasing.com/articit/2221156-

Sappi_looks_on_PAPER.php (access date: 10.01.2012)

7. L. Belov, Logistics today, 2, (2010)

8. L. Belov, Logistics and supply chain management, 6, (2009)

9. A. Schmitt, S. Sun, L. Snyder, Z.-J. Shen, Omega, 52, (2015)

10. T.Vallet-Bellmunt, M. Martínez-Fernández, J. Capó-Vicedo, Industrial Marketing Management, 40, (2011)

11. F. Wiengarten, P. Humphreys, C. Gimenez, R.McIvor, International Journal of Production Economics, 171, 3 (2016)

12. I. Manuj, J.T. Mentzer, International Journal of Physical Distribution \& Logistics Management, 383, (2008) 